\title{
WORLD-METHODOLOGICAL AND HISTORICAL ORIGINS OF CRIME PROBLEMS IN THE AREA OF ILLEGAL TRAFFICKING
}

\section{Kornyakova T. V.}

\section{INTRODUCTION}

The history of the drug has its long-standing roots. In the Middle East in 5000 BC the "grain of joy" was spread, the so-called opium poppy. About $2700 \mathrm{BC}$ used hemp in China in the form of infusion, and tea-emperor Sheng Nung ordered his subjects to take it as a cure for gout and inattention. The Stone Age people were aware of opium, hashish and cocaine, these drugs were used to change their minds and in the process of preparing for battle. Even on the walls of the funeral complexes of the Indians of Central and South America there are images of people with coca leaves dating from the middle of 3,000 BC.

Throughout history, contacts between distant cultures have come about through trade and war, and drug addiction is no exception. As a result of Marco Polo's crusades and travels, Europeans became aware of opium and hashish, which were widespread in the East. After that, as a result of traveling to America, the British, French, Portuguese and Spanish brought to Europe cocaine (from South America), hallucinogens (from Central America) and tobacco (from North America).

Moreover, there was a bilateral exchange between cultures. Ethiopia is considered to be the birthplace of the coffee tree. Acquaintance with Europeans, which took place in the 17th century, when sailors imported coffee beans to South America, which is today the world's largest coffee producer. Alcohol from distillation also came from Europe to America, and cannabis appeared in Chile in 1545 .

At the beginning of 20th century, there were virtually no restrictions on the production and consumption of drugs. Only occasionally attempts have been made to reduce or prohibit the use of 
certain substances, but they have been short-lived and usually unsuccessful.

\section{Historical origins of the production and distribution of narcotic drugs - the opiate group}

The name «opium» comes from the Greek «opium» which means juice. The British Egyptologist R. Thompson in 1924 reported the mention in the ancient Egyptian manuscripts of the procedure for the collection and medical use of opium: «Early in the morning, an old woman, boys and girls collected juice on cuts (poppy capsules) a small iron spoon and then transferred it to a spoon».

According to the historians of Judea, poppy juice is mentioned even in the Bible, in several passages of the Old Testament you can find the word corresponding to the Hebrew «head» and may mean the poppy head. In the Talmud, the meeting of religious-ethical and legal provisions that took place in the IV-V centuries $\mathrm{BC}$, and contains information on medicine, which has a reference to opium, which is expressed by the word Greek etymology - «ophion».

In addition to opium addiction, in the ancient world there were other forms of desire to intoxicate various poisonous substances. Opium had a useful, in some cases, hunger function, the practical use of which proved to be very appropriate for Muslims, among whom there were always several people who could hardly bear the hardships of the rigid month of fasting known as «Ramadan».

The medical use of opium can be identified with the «father of medicine» Hippocrates (440-377 BC) in the works of which mention the properties of 300 medicinal plants, including a substance called «meconin», which is attributed to narcotic action. There is a mention of milk poppy juice and Theophrastus around $350 \mathrm{BC}$. In its use, «meconin» means opium and is recommended for eye diseases and mental disorders.

Opium is beginning to penetrate Europe as a medicine in the era of the crusades of Christian troops in Palestine. Tabernemontanus even wrote a book called «Magsamensaft», which translates to «Poppy Seed Juice», in which he indicated the need for using this potion in clearly defined cases and did not advise him to abuse it. 
The first drug specifically made from opium was prescribed to a patient in the 15 th century by Paracelsus.

The following mention of opium in history is reflected in the description of China's attempt to colonize Britain.

Which was called the opium war because the British traders were importing opium into China. By the middle of the 19th century, several million Chinese had already become addicted to opium. By that time, China had become the world's first opium user, much of which was grown in India and shipped to the country by the British. The Chinese government has enacted many opium import control laws, but none, including a complete ban, has had the desired effect.

The British did not want to reduce the opium trade. This happened for two reasons: first, it made big profits, and secondly, there was no surge in drug addiction in England, although opium was widely used in medicine. In 1839, a conflict erupted: the Chinese government destroyed a large load of opium owned by British and American traders. In order to destroy the destructive effects of opium, the Chinese emperor in 1839 in Canton launched a massive operation to seize and destroy opium stocks. Colonial cargo-drowning ships were drowning in the sea. These actions can be considered, first, in the history of mankind, the state anti-narcotic program. However, such actions by the Chinese authorities did not meet the understanding of the British colonialists, and in response to such actions Britain sent colonial troops to protect their ships.

The first opium war began. Britain was still able to defeat it, and by the Nanking Treaty of 1842, in addition, was granted the right to use the ports of Hong Kong as compensation for the destroyed cargo of opium. Trade continued, and in 1856 led to the Second War, which ended in 1858 and under the terms of the Tiensin Treaty, China continued to import opium, but could already set large customs duties. The opium trade declined and eventually ceased. The victory in this way has brought enormous benefits to the colonialists and, in particular, huge profits have been made by members of the British royal family. So, soon enough, the Chinese began to refocus their agriculture on growing tea and rice on the poppy plantation. However, in implementing the anti-narcotics program in 1905, the Chinese government adopted a phased ban on opium, which was implemented over the next ten years. The fight against drug addiction 
remains one of the priorities of China's public policy - currently one of the most stringent anti-narcotics legislation.

Morphine (an outdated variant of the name morphine) is one of the major alkaloids of opium found in the sleeping pill (Papaver somniferum). Morphine was first extracted from opium in 1804 by German pharmacologist Friedrich Serturner. It was he who gave morphine the name of the dream god in Greek mythology Morpheus, son of Hypnos, the god of sleep.

Morphine was the first purified alkaloid. However, it became widespread only after the invention of the injection needle in 1853. It has been and continues to be used under strict control to alleviate pain.

In addition, it was used as a «cure» for opium and alcohol dependence. The widespread use of morphine during the American Civil War has reportedly led to the emergence of «army disease» (morphine dependence) in over 400,000 people. In small amounts, morphine is also formed during the demethylation of codeine, which occurs inside the human liver. This process occurs after the application of codeinomist drugs. In 1874, diacetylmorphine, better known as heroin, was synthesized from morphine.

Morphine addiction (morphinism) came about after the method of using morphine by subcutaneous injection was invented. Tom de Quincy left an essay «The Confession of an English Opioman» (1822), detailing how morphine drug addiction develops. At the end of the 19th century, German soldiers and officers returning from the Franco-Prussian War of 1870-1871 were morphine in most cases. A large number of soldiers in the conditions of hostilities were stabbing themselves with morphine, which at that time became available and a fashionable stimulant and sedative. In 1879, in one of the works appeared a description of the disease, called «soldier's». At that time, almost every disease in the US Army was treated with opium. In 1880, an international conference announced the emergence of a new drug addiction disease caused by drug abuse.

At the beginning of the 20thcentury, many doctors became morphinists. In the medical environment, it has been suggested that a physician who understands the perniciousness of morphism is able to self-administer morphine on his or her own, avoiding self-destructive passion. Practice has shown that this is a false statement. Mikhail 
Bulgakov, the author of the story Morphine, was a morphinist, but he was cured of drug addiction by his wife's selfless help. Leo Tolstoy in Anna Karenina describes how the main character was addicted to morphine after it was first used to relieve pain in childbirth.

Before heroin synthesis, morphine was the most common narcotic analgesic in the world. Morphine as well as other morphinated alkaloids are found in plants of the genus Poppy, Stephanie, Synodium, moonshine. They are less commonly found in the genera croton, coculus, triclysia, mesothelioma.

\section{Drugs derived from hemp. Hallucinogens. Incentives and drugs of other origin}

For the production of narcotics, almost all varieties of hemp are suitable. The cannabis plant contains «sannabinodes» an alkaloid that causes hallucinations in humans.

The narcotic effect on the organism in the hemp plant is caused by Delta 9 or THC «tetrahydrocannabinol» (a narcotic active component). Derived cannabis, unlike opiates, is not a medicine, but is used solely by drug users. Hemp derivatives are hallucinogens. Depending on the time and method of collection, as well as the method of processing, there are three main drugs of cannabis: marijuana, hashish and hashish.

The oldest and most popular variety of soft intoxicants is the wellknown cannabis (Cannabis sativa). Hemp seeds and potions made from cannabis are found in excavations of Eurasian cultural layers for more than three thousand years (in Siberia, for example, in the crypts of high-ranking mummified persons, snuff boxes with faded inflorescences of the plant were found). Cannabis was also found in ancient Egyptian burials of the third millennium BC.

Originally this plant from Central Asia. It is assumed that it was from here that hemp spread to the east: India and China. From India, cannabis flowed to North Africa and Spain, from where it came to America through seafarers.

Oriental culture retains the most archaic written evidence of marijuana. Fifteenth-century BC Chinese physicians' evidence of cannabis use as a remedy for rheumatic pain and gout has been dated. 
A little later, cannabis was used as a cure for nervous disorders. In India, marijuana has been recognized as a sacred herb.

Hemp was well known in the ancient world. Surgeon Doscorid, who used cannabis for anesthesia, mentions his ability to cause «phantom and insult» (the high-dose cannabis doses requiring the hallucinogenic properties of cannabis resins are required for the analgesic effect). Thanks to Herodotus, there is a description of the cleansing rites of the Scythians, who, hiding in tents, threw hemp seeds at the burning stones and inhaled the vapors of «joy» (5-4 BC).

Legends of cannabis and its use can be found in many religions: in Shinto (Japan), hemp was used to reunite married couples, to banish evil spirits, and to create fun and happiness in marriage; in Hinduism - hemp is a sacred plant that Shiva has ordered to bring from the Himalayas for «enjoyment and human education», in Buddhism hemp is widely used as food and for ritual purposes; the followers of Zarathustra (Magi - Persia, 5-6 centuries BC) practiced religious and medical use of hemp; The Essenes (Ancient Egypt - 1st century BC), Islamic Sufis, Copts (early Egyptian Christians) and many other religious communities knew all about the properties of this plant.

According to German ethnographer Hugo Obermeyer, smoking cannabis with tubes was known to ancient Germans and haloRomantsev in the first century BC. Therefore, the official European history of the humble textile plant hides a deep esoteric and medicinal tradition, which was lost in the "witch hunt». Interesting is the fact that hemp (the oldest and most widespread plant) was first introduced into the classification only in 1753 (K. Linnaeus), another species was described by Lamarck in 1783. According to some reports, early Christian communities encouraged the use of healing herbs, which a wise man should not avoid (Catholic Bible, Sir 38: 4). Cannabis has never disappeared from the eyes of priests: in addition to the wellknown and then used medicinal properties, it provided paper production and oil for lamps. But they deliberately try not to mention him.

Legislative persecution began in the XII century, when the church banned cannabis use in Spain and in the XIII century in France. In 1484, Pope Innocent VIII officially disconnected cannabis medicines, declaring cannabis unenlightened by communion with the satanic 
mass. At the time, the following medicines were allowed for residents of Western Europe: wearing a bird mask (for treating ulcers), bloodletting with pints and quarters (from pneumonia, colds or fever) and prayer asking for healing. The ban on medical use of hemp was lifted only 150 years later. Alcohol, which by that time had already learned to «strengthen», was known to be a legitimate intoxicant.

Since the Middle Ages, the relationship of Western man with cannabis has changed many times, becoming the subject of moral speculation, then touching on economic benefits. While the church persecuted Europeans using cannabis, the Spanish conquerors cultivated it across the globe for the production of sails, ropes, clothing and other purposes, for which the sailors smiled silently. Near the western port cities, hemp fields have often grown, as cannabis fibers are the most durable and waterproof. Of course, both the harvesters and the producers and sailors knew well about the psychoactive properties of this plant.

After the colonization of India and the invasion of Napoleon into Egypt in Europe, renewed interest in hemp products. At the end of the eighteenth century, the Emperor's Life Medicine brought to Paris a whole collection of different varieties of marijuana, and thanks to the secular protege of the French, cannabis was first identified in terms of official culture.

In 1839, the English physician W. Shaughnessy, a member of the Royal Academy of Sciences, published a paper on the successful use of cannabis as an analgesic in the treatment of rheumatism, convulsions and convulsions. At the same time, the official medical use of hemp is spreading in Europe and America: infusion of leaves and inflorescences served as an antispasmodic and hypnotic agent, and light hemp oil was used to relieve inflammation.

Unauthorized use of cannabis was of concern to clergy only and was not legally prosecuted. In 1864, Egypt became the first country (now existing) to ban the use of hemp.

It is known that in the second half of the 19th century, the «Hasgashish Club» was located in Paris on the banks of the Seine, a small society of writers and artists who were fond of exotic potions. «The members of this club regularly met and used hashish in quantities that can be regarded as very large today.» These were eminent writers: S. Baudelaire, T. Gauthier, P. Verlaine, A. Rambo, 
O. Balzac, A. Dumas and others. Thanks to them, hashish has become widely known in the European cultural tradition. At that time, society could not properly explain the effect of the effect of psychedelic plants on humans. Only in the XX century, a wide and often unpredictable range of manifestations of the human unconscious was substantiated in the writings of 3. Freud, KG Jung, A. Adler, W. Reich, O. Ranck, A. Maslow, S. Grof and other famous scientists.

The authentic history of hemp on the American continent begins with the fourteenth century, when the Spaniards brought «grass» and Peru and Chile, although some researchers believe that the plant was known to the indigenous people of the New World long before the invasion of Europeans. Since 1611, hemp has been cultivated in Virginia. The textile and medicinal properties of cannabis were well known to the first US presidents (the government paid grants to hemp farmers). In 1857, the American writer F. Ludlow describes personal experience after receiving a tincture of Indian hemp, confirming the sacred power of this plant. The psychoactive properties of cannabis were admired by G. Toro, G. Melville, and other well-known American writers and philosophers.

Between 1840 and 1900, over one hundred papers on the medicinal properties of cannabis were published in Western medical literature. Until 1937, hemp was the main drug in the treatment of more than 100 different diseases in the US pharmacopoeia: as a remedy for asthma, migraines, herpes, arthritis, rheumatic pain, dysentery, insomnia, and various neurological disorders.

F. Nietzsche, according to the description of his biographer D. Halswy, being a weak and painful man, used hemp infusion, which was the only cure for him in crisis times.

At the beginning of the 20thcentury, smoking «grass» in the United States was widespread mainly among hired Mexican workers. From them originates the well-known name of marijuana (marijuana). At that time in South America and the Caribbean, this tradition was known for half a century. Among white Americans, mass interest in cannabis emerged only after dry law in the 1920s. However, as the state's policy toward opiates and cocaine was determined, this plant weight often came under the close scrutiny of the authorities, and only by virtue of the well-known clinical features of cannabis remained legal. 
In 1937, 46 US states banned marijuana as a «drug that causes violence». This was thanks to Harry Anslinger (1893-1975), who headed the then State Bureau of Drugs. He started a campaign against smoking marijuana: African Americans and Mexicans, according to Anslinger, along with this habit, «spread violence among young Americans.» However, cannabis medication was still used in medicine, and marijuana cigarettes could be purchased over the counter in pharmacies (for smoking in asthma). In 1941, cannabis drugs were excluded from the US Pharmacopoeia. After World War II, in 1948, the same Anslinger led a heated debate with doctors and the public about the continued ban on cannabis. He is now proving that it is the most dangerous drug that can be used by the Communists to turn American soldiers into pacifists.

These triggered responses from the eastern bloc of communist countries, although before that neither Russia nor China, long ago cultivating cannabis for industrial and medical purposes, saw no need to combat the habit of some of its citizens in the grass. However, this time at the third session of the UN General Assembly in Paris on November 19, 1948, the Protocol on International Narcotics Control was signed, among which marijuana was now considered (before that, and mainly opium).

American sociologists report that the pursuit of cannabis, long ago used for industrial purposes, was also profitable for oil magnates, who began to make oils and fibers using new technology. Hemp is a cheap, natural raw material that can compete with «universal» synthetics. From the fifties, thanks to a lively interest in hallucinogens, the popularity of cannabis in the West began to grow rapidly. In the late sixties, smoking in marijuana in the United States became widespread: cannabis became a symbol of the youth movement. Many have seen this not only as a demonstrative rejection of the conventional alcohol tradition, but also as an important step towards improving the psychological atmosphere in society.

However, marijuana remained outlawed. Some famous people went to jails in the 1960s and 1970s for «storing or transporting drugs», as «grass» was very popular, and finding it for the police was no problem. In October 1968, John Lennon and Yoko were arrested during a search of London's Ringo apartment where they were staying. Police charged them with possession of marijuana. For the 
same reasons, John Sinclair, Mick Jagger, Kate Richard, and many other well-known cultural figures went to prison.

Statistical surveys in 1972 showed that more than half of American university students tried «grass» at least once, about 30\% consumed it several times a week, and about 5\% smoked it daily for more than three years. In February 1976, a special annual report to the US Congress provided data showing that more than half of all Americans between the ages of 18 and 25 had tried marijuana at least once.

Wanting to know the dangers of their children, parents deducted money to study the effects of cannabis smoking on human health. The government was willing to support these studies, and soon the fears were reduced. In 1963, following the resignation of Anslinger, doctors were able to resume some cannabis research, which saw great medical and therapeutic potential. ${ }^{1}$

Marijuana is a mixture of crushed cannabis plant parts. Most often, the color and leaves on which the resin accumulates are ground and ground. Female marijuana is commonly used to make marijuana. The main psychoactive component contained in marijuana is tetrahydrocannabinol. The total number of consumers is estimated at 181 million. Smoking marijuana is harmful because inhalation of the results of combustion of organic substances can cause various health problems.

Marijuana is a narcotic drug that is the apex of cannabis with flowers, fruits and leaves (crushed dried or not dried). The content of THC-tetrahydrocannabinol (narcotic active component) in marijuana from is 2 to $4 \%$.

Stimulants: A group of substances from among the stimulants of the nervous system that activate mental activity, stimulate the central nervous system. Cocaine is a white crystalline powder that has a crystalline structure that looks like salt or soda, sparkles in the sun, and is very life-threatening.

Cocaine is the oldest, one of the strongest and one of the most dangerous stimulants of natural origin. Cocaine is found in the leaves

${ }^{1}$ Петросян С. Р. Культура безумия. Проблема популярности психоактивных веществ. 1998. [Электронный ресурс]: Режим доступа: http://ec-dejavu.ru/c2/Cannabis.html. 
of the Coca plant, which sprouts in the tropical zone of South America, which today is our main supplier of cocaine. The indigenous population used the leaves of this plant as a tonic and narcotic drug. The coca plant did not require special care, grew on its own and could be harvested several times a year. In the history of the extinct Inca empire, the use of the leaves of this plant was widespread among the nobility. Warriors and messengers were given leaves before the march, stimulating vitality and suppressing feelings of hunger.

The euphoric state they got as a result of the drug was identified with a visit to the world of spirits, which, in their opinion, strengthened the soul and body. After the conquest of the South American part of South America, Peru, by the Spaniards in the sixteenth century, they attempted to impose a ban on coca, but with strong resistance, they simply took control of all trade. About $70 \%$ of Peru's population was directly or indirectly involved in the trade of this plant, and the Spanish Treasury made huge profits. As a rule, not all the indigenous population consumed coca, and not always, but with the arrival of the Spaniards, everything changed. Forcibly chasing Indians to places of coca collection, difficult working conditions, barbaric attitude towards them, was the cause of mass consumption of coca leaves. Slave Indians who worked on Spanish silver mines provided coca leaves, making it easier to control and operate.

Cocaine was gradually spreading around the world. The first pure cocaine was obtained in 1855 by the German chemist Friedrich Hedke. After that, many chemists continued to work on the chemical structure and formula of cocaine. So in 1859, the German chemist Albert Niemann conducted new research and in 1860 published his dissertation on a new substance - cocaine, which is contained in the leaves of the coca plant. The dissertation earned him a doctorate. It was not until 1897 that Richard Wilstetter was able to synthesize cocaine in the Einhorn laboratory. Well-known writer-psychologist Sigmund Freud, at the beginning of his activity actively recommended cocaine as a stimulant, analgesic drug and helps to cure 
sexual impotence ${ }^{2}$. Psychoanalyst Sigmund Freud, himself a cocaine addict, was the first to widely market cocaine as a tonic for the treatment of depression and impotence.

In 1886, cocaine became even more popular when John Pemberton introduced coca leaves into his new non-alcoholic beverage, Coca-Cola. The euphoric and exciting impact on consumers has contributed to the rise in popularity of the company around the turn of the century. So cocaine began to grow in popularity. From the 1850 s to the early 1900 s, cocaine and opium elixir (magic or medical), tonic and wine were widely used by representatives of all social classes. Cocaine has become a mainstay of the silent movie industry, and messages of support for cocaine came out of Hollywood at the time, affecting millions. Cocaine consumption in society has increased, and the threat posed by cocaine has gradually become more prominent. In 1905, it became popular to inhale cocaine through the nose, and within five years hospitals and medical literature began to report cases of damage to the nasal tissues caused by cocaine use. The increase in cocaine consumption has made it noticeable the problems caused by it. And this, in the end, led to demands from the public to ban cocaine and its mass consumption. In 1903, public pressure forced Coca-Cola to stop using coca in soft drinks. In 1912, the United States government reported that cocaine had caused 5,000 deaths, and by 1922 cocaine was officially banned.

Cocaine is usually consumed with sugar, novocaine, amphetamine and other drugs similar to novocaine. Derived from coca leaves, cocaine was originally synthesized as an analgesic. Most often, cocaine is sniffed - the powder enters the bloodstream through the tissues of the nose. Sometimes it is swallowed or rubbed into other mucous tissues, such as gums. In order to get the drug into the body as quickly as possible, some cocaine addicts are injected into the bloodstream, however, it greatly increases the risk of overdose. Inhaling cocaine in the form of smoke or vapor speeds up the absorption process with less risk for life than injections.

It is only necessary to start using cocaine, as it becomes almost impossible to get rid of its power. Physiologically, cocaine stimulates

${ }^{2}$ История появления и использования кокаина. Narconon. [Электронный pecypc]: Режим доступа: http://www.narcomanii.net/istorcoks. 
nerve endings located in the brain, which track changes in the body, causing euphoria, which is very addictive. But you can repeat the effect only by constantly increasing the dose. Cocaine is considered a «drug for the rich,» but it can be purchased at low prices for a sample. However, as soon as a person is «stuck» in cocaine, its costs sharply soar upwards, depending on how long it takes to quench the habit. The cocaine trade brings in multi-billion dollar profits. Cocaine users include people of all ages, professions and financial backgrounds, not even children. Death from respiratory failure, stroke, hemorrhage into the brain, heart attack - this is the usual end of cocaine happiness. Children of mothers of drug addicts are born with drug addiction. Many have birth defects and many other health abnormalities. But deadly cocaine is still thriving.

Sometimes cocaine is used with other drugs, such as tranquilizers, or mixed with pervitin, marijuana and heroin, which increases the risk of overdose. The dose may be fatal or addictive to all drugs at once.

Immediately after cocaine is high, there is deep depression, irritability and an all-consuming desire to take more drugs. Appetite disappears, sleep, heart rate increases very much, cramps and convulsions reduce muscles. Cocaine changes the perception of the world - a person acts like a paranoid, showing anger, malice, and anxiety. Regardless of the dose of cocaine, it increases the risk of heart attacks and causes respiratory failure, both of which can cause sudden death. Long-term daily cocaine intake leads to insomnia and loss of appetite. A person becomes psychotic and may have hallucinations. As cocaine becomes involved in the process of brain processing of chemicals, it becomes necessary for a person to receive more and more drugs in order to feel «normal.» People who have become addicted to cocaine (as they do with many other drugs) are losing interest in other areas of life. A person's attempt to stop cocaine causes such severe depression that a person goes to anything - even a murder - to get the drug. If cocaine is not obtained, depression can lead to suicide.

Instant Side Effects:

3. Loss of appetite;

4. Fast heartbeat, high blood pressure and temperature;

5. Narrowing of peripheral blood vessels;

6. Shortness of breath; 
7. Pupil enlargement;

8. Restless sleep;

9. Nausea;

10. Excessive arousal;

11. Strange, unstable behavior, tendency to violence;

12. Hallucinations, hyper-excitement and irritability;

13. Touch hallucinations during which the illusion of insects crawling under the skin appears;

14. The greatest need for drugs;

15. Painful anxiety and paranoia;

16. Strong euphoria;

17. Depression;

18. Panic and psychosis;

19. An overdose (even a single one) can lead to seizures, seizures and unexpected death.

Delayed side effects:

1. Cocaine causes irreversible damage to the blood vessels of the heart and brain;

2. High blood pressure leading to heart attacks, stroke and death;

3. Destruction of the liver, kidneys and lungs;

4. Destruction of the tissues of the nose (by inhalation of the drug);

5. Difficulty breathing (when smoking);

6. Infectious diseases and infections during intravenous administration;

7. Loss of appetite and weight;

8. Strong tooth destruction;

9. Auditory and tactile hallucinations;

10. Sexual disorders, reproductive function disorders and infertility (in men and women);

11. Disorientation, apathy and exhaustion;

12. Irritability and mood swings;

13. Dandruff and psychosis;

14. Strong depression;

15. Addictive (even after one reception). ${ }^{3}$

${ }^{3}$ Кокаїн. [Электронный ресурс]: Режим доступа: http://www.netnarkotik.ru/ua_index. 
In addition, cocaine is available in various forms: coca paste, cocaine hydrochloride, crack, and baseball. Coca paste is a relatively inexpensive product obtained by cocaine extraction from coca leaves. Whitish, cream or beige, usually moist, contains soft aggregates that are easily destroyed by the pressure of a finger. In addition to cocaine, it contains substances that are added for extraction, such as manganese carbonate. Cocaine content ranges from 40 to $90 \%{ }^{4}$.

Cocaine medicines are also aqueous solutions of cocaine hydrochloride. White, slightly yellowish or cream powder, is included in the content of solid transparent crystals. The substance obtained directly from the manufacturer or wholesaler is a well-purified product containing $80-95 \%$ cocaine and a minimum of minor alkaloids and ballast. In retail, the original stock is, in most cases, diluted 2-3 times with different impurities. As ballasts, cocaine-like cheap stimulants, amphetamine, caffeine, etc., which are not organoleptic, can be used.

This operation allows almost imperceptibly to dilute the dose 23 times for the client. Also cheaper ballast substances are used powdered sugar, powdered milk - which significantly reduce the effectiveness of the dose, but allow to obtain from the initial dose of 5-6 secondary.

Crack is a cheaper version of cocaine that is intended for smoking. It is a free base obtained by alkaline solvent extraction. Because cocaine hydrochloride is relatively expensive and decomposes at high temperatures, in the late 1970s, its free base was marketed. Due to the higher decomposition temperature, this substance can be introduced into the body by smoking. At the end of the XX century, this type of cocaine spread to the United States and Latin America. It was named after the characteristic shedding that accompanies its smoking, this sound occurs when the crystals of the free base of cocaine are thermally destroyed. The melting point of the crack is $98{ }^{\circ} \mathrm{C}$, which makes it easy to evaporate when smoking without losing its narcotic

4 Веселовская Н. В., Коваленко А. Е. Наркотики. Свойства, Действие, Фармакокинетика, Метаболизм. Пособие для работников наркологических больниц, наркодиспансеров, химико-токсикологических и судебно-химических лабораторий. - Москва : Триада-Х, 2000. - С. 76-79. 
effect. Crack is also used as a warm substance using a heroin-like method of injecting cocaine inside a heated teaspoon.

Speedball is a mixture of crack cocaine and heroin, the most dangerous form of distributed cocaine. The significant health risk is caused by the cross-interaction of the opium drug heroin and the cocaine stimulant. Such a combination can cause serious complications in the functioning of the cardiovascular system, in the future - cross-physical dependence with severe withdrawal syndrome ${ }^{5}$.

\section{CONCLUSIONS}

Various drugs are obtained by processing poppy plants in the factory and in handicrafts. Opiate drugs are «sedative» and inhibit action. This group includes natural and synthetic substances containing morphine compounds. In most cases, they are given intravenously. All natural narcotic drugs come from poppy seeds. All raw opiates from herbal raw materials have an easy binder effect when hit on the tongue. Contains opioid alkaloids - morphine, codeine and others. In the treated form look like solutions. In the case of handicrafts from vegetable raw materials - a brown solution, similar to strongly brewed tea, with a distinct, sometimes sharp smell of vinegar. When settled, it becomes lighter and more transparent, giving a precipitate in the form of small dark particles. This is a bad thing «black solution» or «black». It may also look like a clear solution in ampoules or in vials similar to Penicillin. Such vials can be made of dark glass and have a label like «morphine hydrochloride».

\section{SUMMARY}

The historical stages of the occurrence of narcotic crime and the history of the occurrence and distribution of drugs have been covered in scientific work. The work is structured based on the properties of drugs and their groups. According to which drugs can be divided into: opiates, depressants made from hemp (hallucinogens), stimulants and drugs of other origin. The opiate group includes: opium, heroin,

5 Маркова И. В. Клиническая токсикология детей и подростков. - СанктПетербург : Интермедика, 1998. - Т. 1-й. - С. 147. 
acetylated opium, codeine, etc. Depressants include: barbiturates, tranquilizers, methadone, etc. Drugs made from cannabis plants includea: marijuana, gaish, hashish oil, LSD, phencyclidine, spice, ecstasy, etc. The group of stimulants include: cocaine, amphetamine and others. The content of drugs and their impact on humans, both biologically and socially, have been analyzed.

\section{REFERENCES}

1. Петросян C.P. Культура безумия. Проблема популярности психоактивных веществ. 1998. [Электронный ресурс]: Режим доступа: http://ec-dejavu.ru/c-2/Cannabis.html.

2. История появления и использования кокаина. Narconon. [Электронный pecypc]: Режим доступа: http://www.narcomanii.net/istorcoks.

3. Кокаїн. [Электронный ресурс]: Режим доступа: http://www.netnarkotik.ru/ua_index.

4. Веселовская Н. В., Коваленко А. Е. Наркотики. Свойства, Действие, Фармакокинетика, Метаболизм. Пособие для работников наркологических больниц, наркодиспансеров, химико-токсикологических и судебно-химических лабораторий. - Москва : Триада-Х, 2000. - С. 76-79.

5. Маркова И. В. Клиническая токсикология детей и подростков. - Санкт-Петербург : Интермедика, 1998. - Т. 1-й. C. 147.

Information about the author: Kornyakova T. V., Doctor of Laws, Professor, Head of the Department of Administrative and Criminal Law Oles Honchar Dnipro National University 72, Haharin av., Dnipro, Ukraine 